Editorial

\title{
Saturday night choroido-retinopathy: a rising clinical entity
}

Keywords: Saturday night retinopathy, ischemic choroidoretinopathy, alcohol, complete blindness, prolonged orbital compression, drug abuse

Abbreviations: SNCR, Saturday night choroido-retinopathy; PION, posterior ischemic optic neuropathy

\section{Editorial}

Saturday night choroido-retinopathy (SNCR) is a new and very rare but blinding clinical entity that associates with complete blindness, proptosis, ocular pain, diffuse retinal edema and ophthalmoplegia following the opioid or heavy alcohol-induced prone position. ${ }^{1-4}$ It has been firstly described by Jayam et al in 1974 as the unilateral visual loss due to prolonged pressure on the orbit at stupor and asleep in face-down position. ${ }^{1}$ It has been called with this name because this clinical pathology occurs following heavy alcohol and abuse of methadone at a Saturday night party. ${ }^{1}$

The main retinal findings of SNCR are markedly retinal vasodilation with diffuse retinal edema. Actually, it's pathogenesis has been considered to be similar to that in posterior ischemic optic neuropathy (PION) occurred in which the patients underwent neurosurgery in the prone position. ${ }^{1-4}$

It was initially considered that SNCR develops due to prolonged compression of the globe and orbit resulting central retinal artery occlusion and retinal ischemia. However, it is currently considered that SNCR is an ischemic choroido-retinopathy due to partial or complete occlusion of the ophthalmic artery because of the detection of a total absence in the electroretinography responses under either light- or dark-adapted conditions in this pathology. ${ }^{1-4}$

However, this prolonged orbital compression causes not only blindness due to the choroido-retinal ischemia, but also painful ophthalmoplegia and proptosis due to the ischemia of extraocular muscles. The tissue edema is initiated by the collapse of orbital vessels due to prolonged external orbital pressure and choroidal and retinal ischemia. Once this pathologic orbital pressure discontinued, the ischemic vessels dilate and reperfuse and fluid moves into the surrounding tissues causing orbital edema, proptosis, ocular motility defects, and retinal edema. Although ocular pain and motility defects, proptosis, and retinal edema improve in a few days or weeks; but the severe visual loss remains and then severe retinal and optic atrophy develop..$^{1-4}$

In SNCR, the cherry red spot in the macula on initial stage may be observed. Fundus fluorescein angiography initially may show mild
Volume 9 Issue I - 2019

Burak Turgut, Tamer Demir

Department of Ophthalmology, Onsekiz Mart University, Turkey

Correspondence: Burak Turgut, MD, Prof, Onsekiz Mart University, Faculty of Medicine, Department of Ophthalmology, Çanakkale, Turkey, Tel +90 5337 I2 8389,

Email burakturgut@comu.edu.tr

Received: January 28, 2019 | Published: February 06, 2019

retinal vascular filling and patchy hyper-fluorescence and choroidal leakage.

In conclusion, we aimed to present briefly this rare clinical entity with rising frequency due to the increased rate of drug and opioid abuse. SNCR is a rare and devastating ophthalmic condition that may be on the rise as the incidence of opioid abuse continues to increase. Any case with complete vision loss, ophthalmoplegia, proptosis, and ocular pain should be considered as an ocular emergency and should be researched possible orbital compression syndrome such as SNCR.

\section{Acknowledgments}

None.

\section{Conflict of interest}

The authors declare that there is no conflict of interest regarding the publication of this paper.

\section{Authorship contributions}

All authors have contributed to the concept and design, data collection, literature Search in the work and writing of the manuscript.

\section{References}

1. Jayam AV, Hass WK, Carr RE, et al. Saturday night retinopathy. J Neurol Sci. 1974;22:413-418.

2. Peracha Z, Ahmed SB, Desai A, et al. Saturday night retinopathy: Characterization of a rare ophthalmic condition. Ophthalmic Surg Lasers Imaging Retina. 2016;47(1):85-89.

3. Malihi M, Turbin RE, Frohman LP. Saturday Night Retinopathy with Ophthalmoplegia: A Case Series. Neuroophthalmology. 2015;39(2):7782 .

4. Nguyen HV, North VS, Oellers P, et al. Saturday night retinopathy after intranasal heroin. Journal of VitreoRetinal Diseases. 2018;2(4):227-231. 